\title{
ПРАВОВОЕ ПОЛЕ В СИСТЕМЕ УПРАВЛЕНИЯ ПАРТНЕРСКИМИ ОТНОШЕНИЯМИ ГОСУДАРСТВА И БИЗНЕСА
}

\author{
(C) 2019 Зельднер Алексей Григорьевич \\ доктор экономических наук, профессор, главный научный сотрудник \\ Институт экономики Российской академии наук \\ 117218, г. Москва, Нахимовский пр-т, д. 32 \\ E-mail: tzeldner@gmail.com
}

В статье рассматривается состояние правовой базы государственно-частного партнерства в связи с принятием введенного с 01.01.2016 г. Ф3-224 «О государственно-частном партнерстве, муниципально-частном партнерстве в РФ ...». В статье вносятся предложения по корректировке отдельных норм права закона, которая позволит расширить круг возможностей привлечения частных инвестиций в российскую экономику посредством механизма государственно-частного партнерства.

Ключевые слова: государственно-частное партнерство, право, инвестиции, социально-экономическое развитие.

Важнейшим направлением социально-экономического развития на ближайшие годы выступает реализация двенадцати национальных проектов. Подчеркивая именно их национальный статус, президент страны В. Путин, выступая с посланием Федеральному собранию, отметил: «Наши проекты развития - не федеральные и тем более не ведомственные. Они именно национальные» [1]. Правительство определило объем финансирования национальных проектов на период с 2019 г. по 2024 г. в размере 25,7 трлн. руб. [2]. Самым инвестиционно емким выступает модернизация инфраструктуры: в следующие шесть лет федеральный бюджет потратит на него свыше 3 трлн. руб., еще 3,3 трлн. руб. придутся на внебюджетные источники и регионы $(58,7$ млрд. руб.). За счет этих средств правительство собирается осществить развитие транспортных коридоров «Запад-Восток» и «Север-Юг», а также повышение уровня экономической связанности в России. В итоге развитие инфраструктуры станет самым дорогим из Национальных проектов, на реализацию которого придется четверть общих расходов на нацпроекты [3].

В протоколе заседания Совета при президенте по стратегическому развитию и национальным проектам подчеркивается, что важнейшим партнером государства при их реализации выступает частный бизнес [4]. И в этом плане актуализируется проблема институционального (правового) обеспечения взаимовыгодных партнерских отношений государства и бизнеса с использованием механизма государственно-частного партнерства.
Активному использованию партнерских отношений государства и бизнеса долгое время мешала нерешенность многих правовых проблем, сдерживавших введение механизмов, обеспечивающих установление паритетных отношений между субъектами партнерских отношений. В России медленно решался вопрос о принятии закона о государственно-частном партнерстве. В 2005 г. принимается Закон № 115 «О концессионных соглашениях». В том же году принимается Закон «Об особых экономических зонах Российской Федерации». И только спустя десять лет принимается Федеральный закон «O госдарственно-частном партнерстве, муниципально-частном партнерства в Российской Федерации и внесении изменений в отдельные законодательные акты Российской Федерации» (от 13 июля 2015 г. № 224-ФЗ).

Принятие этого закона - серьезное достижение России в легализации в правом поле экономических отношений государства и частного бизнеса, способствующее решению стратегических задач российской экономики. В Законе (статья 3) подробно раскрывается сущность ГЧП. «Государственно-частное партнерство, муниципально-частное партнерство - юридически оформленное на определенный срок и основанное на объединении ресурсов, распределении рисков сотрудничество публичного партнера, с одной стороны, и частного партнера, с другой стороны, которое осуществляется на основании соглашений... заключенных в соответствии с Федеральным законом в целях привлечения в экономику частных инвестиций, обеспечения 
органами государственной власти и органами местного самоуправления доступности товаров, работ, услуг и повышения их качества» [5]. Закон № 224 от 13.07.15 - это закон прямого действия при заключении и реализации проектов ГЧП, МЧП и не нуждается в соответствующих региональных и муниципальных законодательных актах. В статье 3, п.3 отмечается, что соглашение о государственно-частном партнерстве, соглашение о муниципально-частном партнерства (далее также - соглашение) - это гражданско-правовой договор между публичным партнером и частным партнером, заключенный на срок не менее чем три года в порядке и на условиях, которые установлены настоящим Федеральным законом (ФЗ-224).

Закон достаточно полно определяет общее направление развития правовых основ в сфере ГЧП на всех уровнях: федеральном, региональном и муниципальном. Дана единая терминология и общие условия заключения соглашений о ГЧП для всех субъектов исполнительной власти. В Законе обеспечена гарантия прав и законных интересов партнеров, возникает право собственности у частного партнера на объект партнерского соглашения. Появляется возможность заключения соглашений о ГЧП по предложению частного партнера. Принятие Закона 224Ф3 - серьезное достижение России в расширении внедрения механизмов государственно- и муниципально-частного партнерства в систему управления экономическим развитием России. Учитывая напряженность федерального, региональных и муниципальных бюджетов, Закон о ГЧП может обеспечить существенный приток частного капитала и улучшение социально-экономических показателей России. Однако для повышения роли Закона о ГЧП в решении инфраструктурных проблем следовало бы дополнить его рядом правоприменительных актов, уточняющих и расширяющих целый ряд позиций партнерских отношений. Рассмотрим их более подробно.

Целью Федерального закона № 224 выступает «создание правовых условий для привлечения инвестиций в экономику РФ». В принципах, изложенных в Федеральном законе 224 (ст.4), перечислены такие как «обеспечение конкуренции», а также «отсутствие дискриминации, равноправие сторон соглашения и равенство их перед законом». В то же время, в статье 5 этого закона вводится ограничение на участие в со- глашениях о ГЧП на стороне частного партнера ряда юридических лиц, приводится достаточно обширный перечень юридических лиц, которые не могут быть частными партнерами, среди них государственные и муниципальные унитарные предприятия, некоммерческие организации, публично-правовые компании, хозяйственные товарищества и общества, контролируемые государством.

Ограничения на участие в ГЧП на стороне частного партнерства хозяйственных обществ, предприятий, находящихся под юрисдикцией государства, а также некоммерческих организаций, к которым относятся все государственные корпорации, не только ограничивают возможность их участия в инфраструктурных проектах, но и противоречат Гражданскому кодексу РФ, ограничивая их деятельность. В сложившихся условиях, связанных с реализацией Национальных проектов (2019-2024 гг.), целесообразно пересмотреть реестр хозяйственных обществ с государственным участием для их активного участия в реализации проектов на базе использования механизма ГЧП.

Отметим в связи с этим и правовые особенности госкорпораций. В соответствии с законом «О некоммерческих организациях», к которым отнесены госкорпорации, имущество, переданное им государством, становится собственностью госкорпорации. Собственность некоммерческих организацй (НКО) обладает спецификой как относительно частной собственности, так и относительно собственности государственной. Специфика собственности НКО состоит в предоставлении субъекту хозяйствования более широких полномочий по распоряжению имуществом. «В частности, по сравнению с унитарными предприятиями, функционирующими на основе права хозяйственного ведения, не наделенными в отличие от некоммерческих организаций полномочиями отчуждения или сдачи в аренду недвижимого имущества без согласия государства, а также правом распоряжения всей полученной прибылью. Для НКО эти ограничения снимаются» [6]. Следует иметь ввиду, что федеральные законы о создании госкорпораций - это основной законодательный акт, регулирующий их деятельность, они предоставляют данной конкретной форме НКО дополнительные, более существенные привилегии, нейтрализующие ограничения экономической свободы, имеющие место в отношении других форм некоммерче- 
ских организаций. И это дает им возможность активно участвовать в проектах ГЧП.

В Законе о ГЧП подчеркивается возрастающая роль муниципалитетов в реализации соответствующей их юрисдикции проектов ГЧП, и не случайно Федеральный закон № 224 в своем названии включает словосочетание «муниципально-частное партнерство», для которого конкретизирована специфика партнерских отношений. В статье 18 «Полномочия муниципальных образований в сфере муниципально-частного партнерства» главу муниципального образования в пп. 1-2 наделяют полномочиями координации деятельности и «согласования публичному партнеру конкурсной документации для проведения конкурсов на право заключения соглашений о муниципально-частном партнерстве». Казалось бы, все правовые вопросы полномочий муниципалитетов соблюдены. Но в этой же статье в п.3 ст. 18224-Ф3 даются следующие наставления: «Глава муниципального образования направляет в орган исполнительной власти субъекта Российской Федерации, определенный высшим исполнительным органом государственной власти субъекта Российской Федерации, проект муниципально-частного партнерства для проведения оценки эффективности проекта и определения его сравнительного преимущества ...» [7]. Следует согласиться с мнением о том, что «неясно, о какой процедуре здесь идет речь: об уведомительной, экспертно-оценочной или разрешительной? Может ли исполнительный орган власти субъекта Федерации наложить «вето» на тот или иной проект МЧП? Да и вообще, насколько такая практика соответствует конституционному праву муниципалитетов» [8]. Да и в самом 224-ФЗ важнейшим принципом ГЧП названа свобода заключения соглашений (ст.4 п. 6).

Представляется, что ФЗ-224 недоучитывает конституциональное право органов муниципальной власти, нарушая установленные для них Конституцией полномочия. В Конституции РФ ст. 11 п. 2 отмечается, что «государственную власть в субъектах РФ осуществляет образуемые ими органы государственной власти». А в ст. 12 подчеркивается: «Местное самоуправление в пределах своих полномочий самостоятельно. Органы местного самоуправления не входят в систему государственной власти» [9]

В принципах ГЧП четко обозначено положение о «справедливом распределении рисков и обязательств между сторонами соглашения» (ст. 4 п.5). В соглашении определены порядок и сроки возмещения расходов сторон, но способы исполнения подробно раскрыты только по «обеспечению исполнения частным партнером обязательств по соглашению (предоставление банком или иной кредитной организацией независимой гарантии (банковской гарантии), передача публичному партнеру в залог прав частного партнера по договору банковского счета, страхование риска ответственности частного партнера за нарушение обязательств по соглашению), размеры предоставляемого финансового обеспечения и срок, на который оно предоставляется». Что же касается обязательств публичного партнера, то «в случае досрочного прекращения соглашения, содержащего обязательство частного партнера по передаче публичному партнеру в собственность объекта соглашения, находящегося в собственности частного партнера, объект соглашения подлежит передаче частным партнером публичному партнеру при условии компенсации осуществленных в соответствии с соглашением затрат частного партнера, которая уменьшена на сумму убытков, причиненных публичному партнеру и третьим лицам таким досрочным прекращением (ст. 13 п. 9)» [7].

Неоднозначно смотрится в ФЗ-224 и новелла о том, что положения Закона о ГЧП и МЧП не распространяются на Закон «О концессионных соглашениях» (ФЗ-115 от 21.07.2015). В статье 2 п.2 Ф3-224 отмечается, что «отношения, возникающие в связи с подготовкой, заключением, исполнением и прекращением концессионных соглашений, с установлением гарантий прав и законных интересов сторон концессионного соглашения, регулируются Федеральным законом от 21 июля 2005 года № 115-ФЗ «О концессионных соглашениях».

Справедливости ради следует отметить, что до появления Закона 224-ФЗ, введенного с 1.01 .2016 г. основной законодательно признанной формой государственно-частного партнерства в России были концессионные соглашения. Принятый закон о ГЧП в большей мере защищает частного инвестора, а также предусматривает передачу объекта партнерских соглашений в частную собственность. В концессионном соглашении сохранялись более существенные риски с возвратом частных инвестиций. Имеются и другие различия.

Учитывая, что в силу своего монопольного положения «концессии играют доминирующую 
роль в ГЧП. На них приходится более $80 \%$ общего числа проектов ГЧП и 73\% их стоимости. Самые капиталоемкие проекты в сферах энергетики, транспорта осуществляются именно на условиях концессий» [10], было бы целесообразно унифицировать в этих двух законах наиболее прогрессивные положения и жестко не делить их по объектам соглашения.

Следует также обратить внимание на ограничение в подходах к использованию в соглашениях возможностей иностранных физических или юридических лиц (ст. 5 п. 10). Речь идет о технических средствах обеспечения функционирования объектов информационных технологий (ст. 7 п. 19). «Ограничения для иностранных партнеров, участвующих в проектах ГЧП,- скорее, следствие общей кампании по импортозамещению, чем логика здравого смысла. Кроме того, что это противоречит мировой практике, мы лишаемся не только инвестиций, но и новейших технологий, что для современного этапа развития России исключительно актуально» [11].

В Федеральном законе 224 дан подробный перечень объектов соглашений. При этом объектом соглашения может быть только имущество, в отношении которого не установлена принадлежность к государственной или муниципаль- ной собственности, либо имеется запрет на отчуждение в частную собственность. Однако ряд объектов в этот перечень не попали. 224-Ф3 при перечне объектов соглашений о ГЧП и МЧП не включены такие инфраструктурные объекты массового распространения как коммунальное хозяйство, включающее теплоснабжение, водоснабжение, газификацию сел и др.

Принятие Ф3-224 - это большой прорыв в системе управления социально-экономическим развитием страны. Грамотное использование закона позволит в значительной степени легализовать (при соответствующих гарантиях) и привлечь частный капитал в реализацию инфраструктурных проектов.

Оценивая принятый Федеральный закон «О государственно-частном партнерстве, муниципально-частном партнерстве в Российской Федерации...» № 224 и вступивший в силу с 1.01.2016 г. как существенное продвижение в обеспечении правового статуса ГЧП, следует учитывать, что это рамочный закон, требующий глубокой проработки подзаконной нормативной базы, учитывающей специализацию объектов соглашений. Это обеспечит существенную эффективность его применения.

\section{Библиографический список}

1. Российская газета. 21.02.2019.

2. https://mail-attachment.googleusercontent.com/attachment/u/0/?view=att\&th=168f136b914a51b3\&attid=0.5\& disp=vah\&safe $=1 \& z w \&$ saddbat $=$ AN

3. https://www.rbc.ru/economics/19/02/2019/5c6ac3339a79471423e559c7

4. https://www.rbc.ru/rbcfreenews/5bdd94b19a79477095bcdbcf?from...

5. Федеральный закон «О государственно-частном партнерстве, муниципально-частном партнерстве в Российской Федерации и внесении изменений в отдельные законодательные акты Российской Федерации» от 13 июля 2015 г. № 224-ФЗ. Российская газета. 17.07.2015.

6. Сильвестров С., Зельднер А. Госкорпорации в экономике России. М. ИЭ РАН. 2008. С. 8-9.

7. http://www.consultant.ru/cons/cgi/online.cgi?req=doc \&base=LAW \&n=303642 \&fld=134\&dst=000000001,0 \& r nd $=0,2559285283885451 \# 0634536$...

8. Бухвальд Е. М. Муниципально-частное партнерство. Новый этап. Ж. Самоуправление. 2015. № 7-8. С. 16.

9. Конституция Российской Федерации. М. Ось-89. 2001. С. 6

10. Варнавский В. и др. Основы государственно-частного партнерства (теория, методология, практика). М. Анкил. 2015. С. 63

11. Зельднер А.Г. Национальная модель социально-рыночного развития России на базе смешанной экономики и механизма государственно-частного партнерства. М. Анкил. 2017. С. 75

12. Зельднер А.Г., Осипов В.С. Системные дисфункции государственного управления: институциональный подход // Экономика и предпринимательство. 2015. № 8-2 (61-2). С. 127-131

13. Панова Т.В. Становление государственно-частного партнерства в России: содержание и формы // Экономические науки. 2014. № 115. С. 22-25. 